\title{
Anticaries Potential of a Fluoride Mouthrinse Evaluated In Vitro by Validated Protocols
}

\author{
Gisele Pedroso MOI \\ Lívia Maria Andaló TENUTA \\ Jaime Aparecido CURY
}

Dental School of Piracicaba, State University of Campinas, Piracicaba, SP, Brazil

\begin{abstract}
This blind and randomized study tested in vitro, using validated protocols, the anticaries potential of an experimental fluoride mouthrinse. One-hundred enamel slabs, half sound and half with caries-like lesions (carious), all with known surface microhardness (SMH), were submitted to 3 treatment groups: A) a placebo mouthrinse (negative control); B) a positive control mouthrinse containing $0.05 \% \mathrm{NaF}$; and $\mathrm{C}$ ) an experimental formulation containing $0.05 \% \mathrm{NaF}$ and cetylpyridinium chloride as an antibacterial substance. To evaluate the formation of $F$ products on enamel, sound $(n=10)$ and carious $(n=10)$ slabs were treated with the formulations during $10 \mathrm{~min}$ and loosely and firmly-bound $\mathrm{F}$ formed in enamel were determined after extraction with alkali and acid, respectively. To evaluate the inhibition of enamel demineralization, sound enamel slabs $(n=10)$ were treated with the mouthrinse formulations $2 \mathrm{x}$ /day during $1 \mathrm{~min}$ and subjected to a $\mathrm{pH}$-cycling regimen simulating a cariogenic challenge (demineralization). To evaluate enamel remineralization, the carious slabs $(\mathrm{n}=10)$ were submitted to the treatments $3 \mathrm{x} /$ day and subjected to a $\mathrm{pH}$-cycling model simulating a remineralizing condition. After 8 days, enamel SMH was determined again and the percentage of SMH loss or SMH recovery was calculated for the sound and carious slabs, respectively. The experimental formulation was superior to the negative control $(\mathrm{p}<0.05)$ and equivalent to the positive control $(\mathrm{p}>0.05)$ in the formation of $\mathrm{F}$ products in enamel, and in the inhibition of enamel demineralization and enhancement of remineralization. These data suggest that the tested experimental fluoride mouthrinse has anticaries potential.
\end{abstract}

Key Words: fluoride, mouthrinse, demineralization, remineralization, enamel, fluoride uptake.

\section{INTRODUCTION}

Fluoride (F) has played an important role in dental caries control and it has been added to several commercial products for individual and professional use (1). However fluoride is very reactive and it can be inactivated by other chemical components present in commercial products (2). Therefore, any commercial product should be checked for $\mathrm{F}$ activity to control caries before being available for general use.

Several methods have been proposed to evaluate the anticaries potential of commercial $\mathrm{F}$ formulations, and in vitro studies simulating the physicochemical effect of $F$ on caries have been extensively used (3). However, in vitro models should be previously validated in terms of dose-response $(4,5)$ to differentiate the anticaries potential of different $\mathrm{F}$ formulations.
It is well known that $\mathrm{F}$ applied on tooth surfaces reacts with either enamel or dentin forming two products, named loosely-bound $\mathrm{F}$ (calcium-fluoride like, $\mathrm{CaF}_{2}$ ) and firmly-bound $\mathrm{F}$ (fluorapatite, FA). Since $\mathrm{CaF}_{2}$ has been considered the responsible for the effect of $\mathrm{F}$ on caries control (6), the evaluation should be focused mainly on the ability of $\mathrm{F}$ formulations to form this kind of compound. Also, the formation of this F reservoir in carious enamel is also related to the clinical anticaries efficacy of the commercial $F$ formulation used (7).

Furthermore, in the evaluation of a new F formulation, it is important to show that $\mathrm{F}$ products formed on enamel are able to interfere with the dynamics of caries development (6). Thus, pH cycling models simulating dental caries process should be used to evaluate the effect of $F$ on the reduction of enamel demineralization and enhancement of remineralization (2).

Correspondence: Prof. Dr. Jaime A. Cury, Avenida Limeira, 901, 13414-903 Piracicaba, SP, Brasil. Tel/Fax: +55-19-2106-5302. e-mail: jcury@fop.unicamp.br 
Therefore, the aim of the present study was to evaluate, using validated protocols, if a fluoride mouthrinse is more efficacious than a placebo formulation and at least equivalent to a positive control in the reaction with sound and carious enamel to form $\mathrm{F}$ products, and also if it is able to inhibit enamel demineralization and enhance its remineralization.

\section{MATERIAL AND METHODS}

\section{ExperimentalDesign}

This blind and randomized study evaluated in vitro, using previously validated protocols $(8,9)$, the anticaries potential of a new fluoride mouthrinse. Randomized groups of 10 enamel slabs each were used to evaluate the following mouthrinse formulations: A) negative control formulation, without $\mathrm{F}$ or cetylpyridinium chloride (CPC), but containing all the other ingredients present in the experimental formulation; B) positive control, same formulation as that of the experimental formulation, but containing $0.05 \% \mathrm{NaF}$ and no $\mathrm{CPC}$; and $\mathrm{C}$ ) experimental formulation, containing $0.05 \%$ $\mathrm{NaF}$ and $0.05 \% \mathrm{CPC}$ and other ingredients. The formulations were prepared and codified by the company Colgate-Palmolive from Brazil (Colgate-Palmolive Indústria e Comércio Ltda., São Bernardo do Campo, SP, Brazil). The experimental formulation is currently named Prevident ${ }^{\circledR} 220$. The response variables studied were: $\mathrm{CaF}_{2}$ and $\mathrm{FA}$ formed in sound and carious enamel by the formulations, and enamel surface microhardness loss (\%SML) and recovery (\%SMR), lesion depth (LD) and total fluoride (TF) in enamel after the $\mathrm{pH}$-cycling regimens and treatments with the formulations. Independent statistical comparisons among treatments were made for sound and carious enamel.

\section{Preparation of Sound and Carious Enamel Slabs}

Two hundred and forty enamel slabs $(4 \times 4 \times 3$ $\mathrm{mm}$ ) were obtained from bovine incisor teeth that were stored in $2 \%$ formaldehyde solution (10). The slabs were polished flat and 160 slabs were selected based on baseline surface microhardness (SMH) (mean 312.4 $\mathrm{kg} / \mathrm{mm}^{2}$, SD 15.0). SMH was measured using a microhardness tester (Future-Tech Corp., Tokyo, Japan) with Knoop diamond under a 25 -g load for $5 \mathrm{~s}$ (11), by making 3 indentations spaced $100 \mu \mathrm{m}$ from each other at the center of enamel surface.

The area of enamel surface was measured and all slab surfaces were protected with wax, except for the enamel surface. Sixty slabs were randomly grouped as sound and were kept at $4^{\circ} \mathrm{C}$ in humid environment until analyses. The remaining 100 slabs were immersed (at 2 $\mathrm{mL}$ solution per $\mathrm{mm}^{2}$ of enamel) in $0.1 \mathrm{M}$ acetate buffer pH 5.0 containing $1.28 \mathrm{mM} \mathrm{Ca}, 0.74 \mathrm{mMP}_{\mathrm{i}}$ and $0.03 \mu \mathrm{g}$ $\mathrm{F} / \mathrm{mL}$, during $16 \mathrm{~h}$ at $37^{\circ} \mathrm{C}$ (9), to create caries-like lesions. SMH was measured again by making 3 indentations located $150 \mu \mathrm{m}$ away from the previous ones, and 60 slabs with a mean SMH of $27.2 \pm 7.6 \mathrm{~kg} /$ $\mathrm{mm}^{2}$ were selected for the tests with carious enamel.

The selected 60 sound enamel slabs and the 60 carious ones were randomized to six groups of 10 slabs each for the tests.

\section{Reactivity Test}

Groups of 10 sound and 10 carious slabs were immersed in the treatment solutions $\left(1 \mathrm{~mL} / \mathrm{mm}^{2}\right.$ of enamel area) under agitation $(100 \mathrm{rpm})$ and at room temperature (8). After $10 \mathrm{~min}$, the slabs were removed and washed with distilled water (DW) during $1 \mathrm{~min}$.

Immediately after the reactivity test, each slab was individually immersed in $0.5 \mathrm{~mL}$ of $1.0 \mathrm{M} \mathrm{KOH}$ solution for $\mathrm{CaF}_{2}$ extraction (12). After $24 \mathrm{~h}$ at room temperature and under agitation (100 rpm), the extract was buffered with $0.5 \mathrm{~mL}$ TISAB II $(1.0 \mathrm{M}$ acetate buffer pH 5.0,1M NaCL and 0.4\% CDTA) containing 1.0 M HCL. The slabs were removed and washed for 30 $\mathrm{s}$ with DW.

After $\mathrm{CaF}_{2}$ extraction, each slab was immersed in $0.25 \mathrm{~mL}$ of $0.5 \mathrm{M} \mathrm{HCL}$ for $30 \mathrm{~s}$ under agitation to remove an enamel layer and quantify FA formed in enamel. The extract was buffered with the same volume of TISAB II pH 5.0 containing $0.5 \mathrm{M} \mathrm{NaOH}$ (13). Due to difference of composition between sound and carious enamel, the data were expressed as $\mu \mathrm{g} \mathrm{F} / \mathrm{cm}^{2}$ rather than in ppm (10).

\section{Inhibition of Enamel Demineralization Using a $\mathrm{pH}$ - Cycling Model}

The $\mathrm{pH}$-cycling model used in this study simulates a cariogenic clinical condition where the demineralizing condition is higher than the opposed remineralizing (De>Re). It was previously validated showing dose- 
response effect to $\mathrm{F}$, i.e., the inhibition of enamel demineralization is proportional to $\mathrm{F}$ concentration of the treatment made on enamel during the $\mathrm{pH}$-cycling (9).

Sound slabs $(n=10)$ were individually immersed for $4 \mathrm{~h}$ in the demineralizing solution described above to provoke caries-like lesions $\left(3 \mathrm{~mL} / \mathrm{mm}^{2}\right)$ and for $20 \mathrm{~h}$ in a remineralizing solution $\left(1.5 \mathrm{~mL} / \mathrm{mm}^{2}\right)$ containing 1.5 mM Ca, 0.9 mM P, 150 mM KCL, $0.05 \mu \mathrm{g} \mathrm{F/mL,} 0.1$ $\mathrm{M}$ Tris buffer, $\mathrm{pH}$ 7.0. This cycle was repeated for 8 days, at $37^{\circ} \mathrm{C}$. Twice a day (before and after immersion in the demineralizing solution), the slabs were briefly washed with DW and immersed in one of the mouthrinse formulations for $1 \mathrm{~min}$ under agitation at room temperature. The $\mathrm{pH}$-cycling solutions were replaced on the 4th day by fresh ones. After the 8th cycle, the slabs remained in the remineralization solution for an additional 24-h period (11).

Enamel SMH was measured again by making 3 indentations spaced $150 \mu \mathrm{m}$ from the baseline ones. The percentage of surface microhardness loss (\%SML) was calculated using the equation: $\% \mathrm{SML}=$ (sound $\mathrm{SMH}-\mathrm{SMH}$ after $\mathrm{pH}$-cycling)/ sound $\mathrm{SMH}) * 100$.

\section{Enamel Remineralization in a $\mathrm{pH}$-Cycling Model}

The model used simulates a situation where the remineralizing condition is higher than the demineralizing ( $\mathrm{Re}>\mathrm{De}$ ), and was also validated showing doseresponse effect to $F$, i.e., enhancement of enamel remineralization proportional to the $\mathrm{F}$ concentration used as a treatment in the cycling model (9). Carious enamel slabs were kept for $2 \mathrm{~h}$ in the demineralizing and for $22 \mathrm{~h}$ in the remineralizing solution described above, daily, at $37^{\circ} \mathrm{C}$, during 8 days. Three times a day (soon after, $3 \mathrm{~h}$ before and $3 \mathrm{~h}$ after immersion in the demineralizing solution), the slabs were washed with DW and immersed in one of the treatments for $1 \mathrm{~min}$ under agitation at room temperature. After the treatments, the blocks were washed again. On the 4th day, the de- and remineralizing solutions were replaced by fresh ones.

SMH was measured again by making a new row of 3 indentations spaced $150 \mu \mathrm{m}$ from the previous ones, and the percentage of surface microhardness recovery $(\% \mathrm{SMR})$ was calculated using the folowing equation: $\% \mathrm{SMR}=(\mathrm{SMH}$ after $\mathrm{pH}$-cycling $-\mathrm{SMH}$ after caries-like lesion)/(sound SMH - SMH after caries-like lesion) $* 100$.

\section{Lesion Depth Determination and F Concentration in pH-Cycled Slabs}

After final SMH determination, the slabs were longitudinally sectioned through the center using a water-cooled diamond saw, in a hard-tissue microtome. One half of the slab was used for lesion depth determination using polarized microscopy analysis and the other half for total $\mathrm{F}$ determination.

Longitudinal sections $(100 \pm 10 \mu \mathrm{m})$ were obtained from the central part of one half of each slab, which were immersed in DW and mounted in glassslides. The artificial caries lesion depth was analyzed with a polarized light microscope (DM LSP: Leica, Wetzlar, Germany) at $\times 20$. Digital images were obtained and the lesion depths were measured at 3 sites using Image-Pro Plus software (Media Cybernetics, Silver Spring, MD, USA). The three measurements were averaged.

Total fluoride $\left(\mathrm{CaF}_{2}+\mathrm{FA}\right)$ was extracted from the other halves of each slab submitted to the $\mathrm{pH}$ cycling regimens. The area of enamel surface was measured and all the slab surfaces were protected with a layer of acid-resistant varnish, except for the enamel surface. Three sequentially layers of the enamel were removed by immersion in $0.50 \mathrm{~mL}$ of $0.5 \mathrm{M} \mathrm{HCL}$ under agitation for 15, 30 and $60 \mathrm{~s}$, and the amount of $\mathrm{F}$ found in each layer were then summed and expressed as $\mu \mathrm{g} \mathrm{F}$ / $\mathrm{cm}^{2}(10)$.

\section{Fluoride Determination}

The concentration of $\mathrm{F}$ as $\mathrm{CaF}_{2}, \mathrm{FA}$ and total $\mathrm{F}$ $\left(\mu \mathrm{g} \mathrm{F} / \mathrm{cm}^{2}\right)$ were determined in the extracts using an ion-selective electrode (Orion 96-09; Orion Research Inc., Boston, MA, USA) and an ion analyzer (Orion EA940), previously calibrated with standard F solutions containing 0.1 to $16 \mu \mathrm{g} \mathrm{F} / \mathrm{mL}$ prepared according to the reagents used in each determination.

\section{Statistical Analysis}

Independent statistical comparisons among treatments were made for sound and carious enamel. For all analyses, ANOVA was used, followed by Tukey's test. The assumptions of equality of variances and normal distribution of errors were previously checked for all response variables (14). For all analyses, SAS System 
8.01 software (SAS Institute Inc., Cary, NC, USA) was used and the significance level was set at $5 \%$.

\section{RESULTS}

The amount of loosely-bound $\mathrm{F}\left(\mathrm{CaF}_{2}\right)$ deposited on sound and carious enamel was statistically similar after treatment with the positive control and experimental formulations ( $p>0.05)$, but was significantly higher than that found on the slabs treated with the negative control formulation $(\mathrm{p}<0.05)$ (Fig. 1). The firmlybound F(FA) formed on the sound enamel slabs was not significantly different among the three formulations $(p<0.05)$. However, the amount of FA formed on the carious enamel slabs was significantly higher for the positive control and experimental formulations in comparison to the negative control $(\mathrm{p}<0.05)$, and did not differ significantly from each other $(\mathrm{p}>0.05)$. Figure 1 shows that the amount of $\mathrm{F}$ products formed on enamel was higher for the carious slabs than for the sound slabs.

Mineral loss evaluated by the \%SML and lesion depth (LD) was significantly higher in slabs treated with the negative control formulation $(\mathrm{p}<0.05)$. No statistically significant difference was observed between the positive control and the experimental formulation ( $p>0.05)$ (Fig. 2 ). As a result of the $\mathrm{pH}$-cycling, total $\mathrm{F}$ concentration at the end of the cycling was significantly higher in enamel slabs treated with the positive control and experimental formulations $(\mathrm{p}<0.05)$ (Fig. 2).

When the carious enamel slabs were submitted to the $\mathrm{pH}$ cycling, the \%SMR was significantly higher for

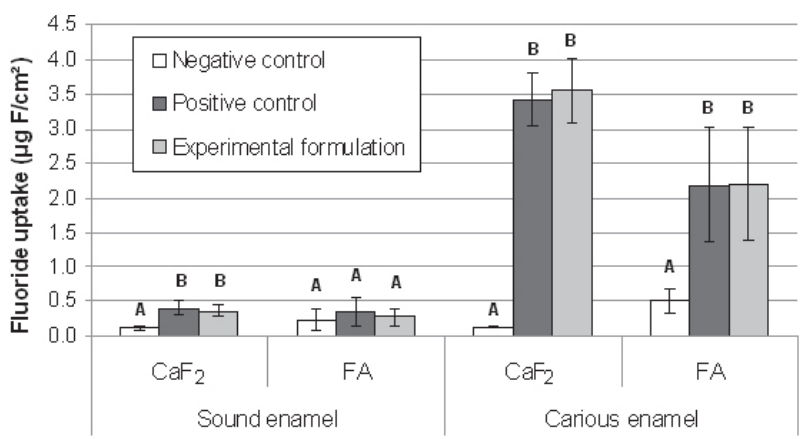

Figure 1. Fluoride $\left(\mu \mathrm{g} \mathrm{F} / \mathrm{cm}^{2}\right)$ formed in sound and carious enamel as $\mathrm{CaF}_{2}$ and $\mathrm{FA}$, according to the treatments (mean $\pm \mathrm{SD} ; \mathrm{n}=10$ ). Different letters represent significant differences among the different formulations $(\mathrm{p}<0.05)$. the positive control and experimental formulations when compared to the negative control $(\mathrm{p}<0.05)$ (Fig. 3). The lesion depth also decreased significantly in these groups ( $<<0.05)$ (Fig. 3). After the $\mathrm{pH}$ cycling, the amount of total $\mathrm{F}$ in the carious enamel slabs was significantly increased for the positive control and experimental formulations $(\mathrm{p}<0.05)$ (Fig. 3).

\section{DISCUSSION}

Anticaries effect of $\mathrm{F}$ formulations can be modified by $\mathrm{F}$ interactions with other formula components

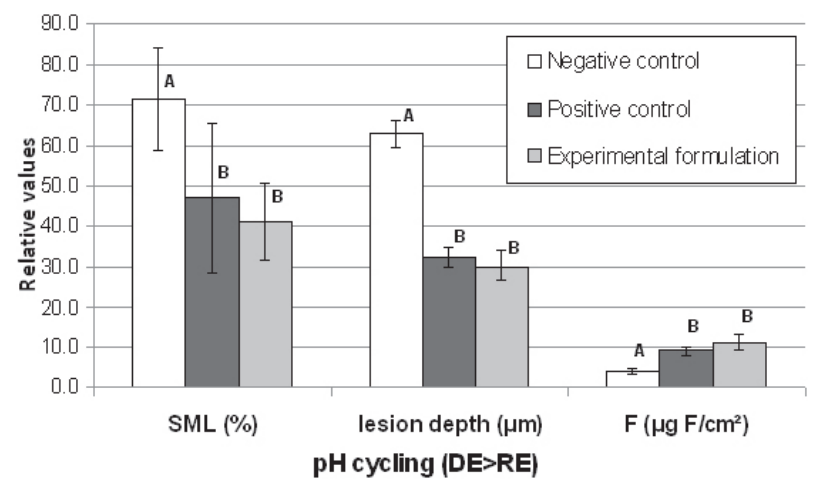

Figure 2. Enamel surface microhardness loss (\%SML), lesion depth $(\mu \mathrm{m})$ and total fluoride in enamel $\left(\mu \mathrm{g} \mathrm{F} / \mathrm{cm}^{2}\right)$ after the demineralizing (De>Re) pH-cycling regimen, according to the treatments (mean $\pm \mathrm{SD} ; \mathrm{n}=10$ ). Different letters represent significant differences among the different formulations $(\mathrm{p}<0.05)$.

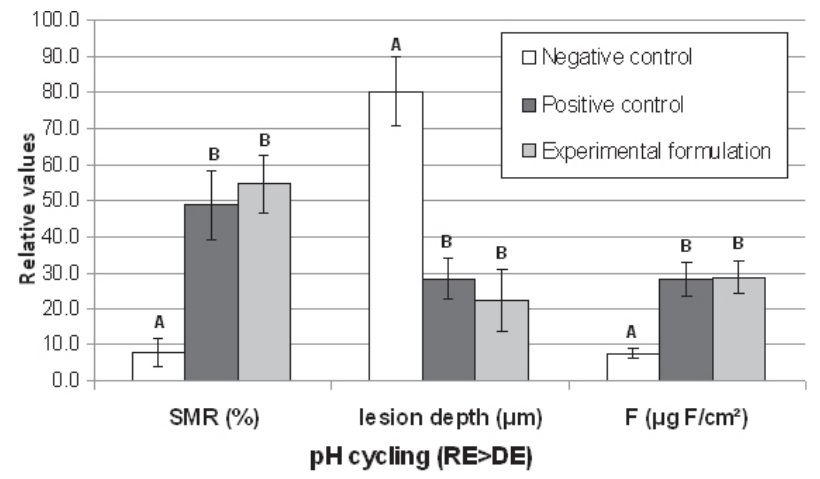

Figure 3. Enamel surface microhardness recovery (\%SMR), lesion depth $(\mu \mathrm{m})$ and total fluoride in enamel $\left(\mu \mathrm{g} \mathrm{F} / \mathrm{cm}^{2}\right)$ after the remineralizing $(\mathrm{Re}>\mathrm{De}) \mathrm{pH}$-cycling regimen, according to the treatments (mean $\pm \mathrm{SD} ; \mathrm{n}=10$ ). Different letters represent significant differences among the different formulations $(\mathrm{p}<0.05)$. 
(2) or still by the interaction of these components with the dental surface (15), reducing $F$ uptake (16).

The findings clearly showed that the tested formulation presents anticaries potential because it was able not only to incorporate F in enamel (Fig. 1), but also to interfere with the phenomena of caries development, reducing enamel demineralization (Fig. 2) and enhancing remineralization (Fig. 3). This effect was superior to that of the negative control and equivalent to that of the positive control, showing that the other components of the formulation did not reduce the F effect.

With regard to the reactivity test, the main product formed on enamel was loosely-bound $\mathrm{F}\left(\mathrm{CaF}_{2}\right)$. This result is relevant because there is a consensus that $\mathrm{CaF}_{2}$ may be considered more important than firmlybound $\mathrm{F}$ (FA) on caries control (6). Also, the concentration of $\mathrm{CaF}_{2}$ formed on carious enamel was higher than that formed on sound enamel, which may be explained by the increased porosity of the carious enamel, increasing the reaction area $(2,17)$. Although FA is not considered the most important product formed in enamel by topical F, some effect on caries control cannot be discarded (18). Thus, the data of the present study showed that the ability of the F formulations to form FA in sound enamel was not different than that of the negative control (Fig. 1). However, the experimental formulation was statistically superior to the negative control on the formation of FA in carious enamel. Since the in vitro reactivity of $\mathrm{F}$ formulation with demineralized enamel correlates with its clinical anticaries effect (7), the present findings suggest that carious enamel should be preferably used to evaluate in vitro the anticaries potential of $\mathrm{F}$ products.

Additionally to F uptake assessments, pH-cycling models (9) were used to evaluate the anticaries potential of experimental formulation simulating two distinct clinical situations, a high and a low cariogenic challenge, to differentiate the effect of the treatments in caries progression and reversal (2). After each $\mathrm{pH}$ cycling regimen (9), it was possible to demonstrate that the experimental formulation has anticaries potential either to inhibit enamel demineralization (Fig. 2) or to enhance remineralization (Fig. 3) compared with the negative control. Additionally, it was equivalent to the positive control, showing that the other components of the formulation do not impair the $\mathrm{F}$ effect to interfere with caries control. It should be emphasized that mineral loss or gain was assessed by $\mathrm{SMH}$ and depth of caries lesions (Figs. 2 and 3) and the data were consistent. Furthermore, F-treated enamel gained $\mathrm{F}$ after the $\mathrm{pH}-$ cycling regimens (Figs. 2 and 3). It is known that enamel can acquire resistance to further demineralization after a cariogenic challenge in the presence of $\mathrm{F}$, and this increase of $\mathrm{F}$ (Figs. 2 and 3 ) may contribute for this effect.

In summary, the experimental mouthrinse evaluated in the present study presents active $\mathrm{F}$ with anticaries potential.

\section{RESUMO}

Este estudo in vitro, cego e randomizado avaliou o potencial anticárie de uma formulação experimental de enxaguatório fluoretado $(\mathrm{F})$, usando protocolos previamente validados. Blocos de esmalte (120), 60 hígidos e 60 com lesão artificial de cárie, com microdureza de superfície (MDS) conhecida, foram submetidos a 3 grupos de tratamentos: A) Enxaguatório placebo (controle negativo); B) Controle positivo contendo $\mathrm{NaF} 0,05 \%$ e C) Uma formulação experimental contendo $\mathrm{NaF} 0,05 \%$ e cloreto de cloreto de cetil-piridínio como antibacteriano. Para testar a capacidade de formação de produtos fluoretados no esmalte, blocos hígidos $(n=10)$ e cariados $(n=10)$ foram tratados durante 10 min e os fluoretos fracamente e fortemente ligados formados foram determinados após extração com álcali e ácido, respectivamente. Para avaliar a inibição da desmineralização do esmalte, os blocos hígidos $(\mathrm{n}=10)$ foram tratados com as formulações $2 \mathrm{x} /$ dia durante 1 min e submetidos a um modelo de ciclagem de $\mathrm{pH}$, simulando o processo de desmineralização. Para avaliar a ativação da remineralização do esmalte, os blocos com lesões de cárie $(\mathrm{n}=10)$ foram tratados $3 \mathrm{x} /$ dia e submetidos a um modelo de ciclagens de pH, simulando uma condição de remineralização. Após 8 dias, a MDS do esmalte foi novamente determinada e as porcentagens de sua redução ou aumento foram calculadas, respectivamente para os blocos hígidos ou com lesão de cárie. A formulação experimental foi superior ao controle negativo $(\mathrm{p}<0,05)$ e equivalente ao positivo $(\mathrm{p}>0,05)$, na formação de produtos fluoretados no esmalte e na inibição de sua desmineralização e ativação da remineralização. Conclui-se que o enxaguatório experimental apresenta fluoreto ativo com potencial para controlar cárie dental.

\section{ACKNOWLEDGEMENTS}

The authors would like to thank Mr. Waldomiro Vieira Filho, from the Dental School of Piracicaba, State University of Campinas, for technical assistance. The last author, authorized by the State University of Campinas, was a scientific consultant to Colgate-Palmolive from Brazil during the course of this study.

\section{REFERENCES}

1. Ellwood R, Fejerskov O, Cury JA, Clarkson B. Fluoride in caries control. In: Dental caries: The disease and its clinical 
management. Fejerskov O, Kidd E (Editors). 2nd. ed. Oxford: Blackwell \& Munksgaard; 2008. p. 287-323.

2 . White DJ. The application of in vitro models to research on demineralization and remineralization of the teeth. Adv Dent Res 1995;9:175-193.

3. White DJ. The comparative sensitivity of intra-oral, in vitro, and animal models in the 'profile' evaluation of topical fluorides. J Dent Res 1992;22:27-36.

4. Proskin HM. Statistical considerations related to intra-oral studies. J Dent Res 1992;71:901-904.

5. White DJ. Reactivity of fluoride dentifrices with artificial caries. I. Effects on early lesions: F uptake, surface hardening and remineralization. Caries Res 1987;21:126-140.

6. ten Cate JM. Review on fluoride, with special emphasis on calcium fluoride mechanisms in caries prevention. Eur J Oral Sci 1997;105:461-465.

7. Raven SJ, Schäfer F, Duckworth RM, Gilbert RJ, Parr TA. Comparison between evaluation methods for the anticaries efficacy of monofluorophosphate-containing dentifrices. Caries Res 1991;25:130-137.

8. Arthur RA, Giancristófaro M, Tabchoury CPM, Cury JA. In vitro study of dose-response relationship of fluoride with dental enamel. Rev Odonto Cienc 2007;55:10-15.

9. Queiroz C, Hara AT, Paes Leme AF, Cury JA. pH-Cycling models to evaluate the effect of low fluoride dentifrice on enamel de- and remineralization. Braz Dent J 2008;19:21-27.

10. Delbem AC, Carvalho LPR, Morihisa LKU, Cury JA. Effect of rinsing with water immediately after APG gel application on enamel demineralization in situ. Caries Res 2005;39:258260.

11. Argenta RMO, Tabchoury CPM, Cury JA. A modified pHcycling model to evaluate fluoride effect on enamel demineralization. Braz Oral Res 2003;17:241-246.

12. Caslavska V, Moreno EC, Brudevold F. Determination of the calcium fluoride formed from in vitro exposure of human enamel to fluoride solutions. Arch Oral Biol 1975;20:333339.

13. Koo H, Cury JA. Soluble calcium/SMFP dentifrice: effect on enamel fluoride uptake and remineralization. Am J Dent 1998;11:173-176.

14. Box GEP, Hunter WG, Hunter JS. Statistics for experimenters: an introduction to design, data analysis, and model building. New York: John Wiley \& Sons Inc.; 1978.

15. Franco EM, Cury JA. Effect of Plax prebrushing rinse on enamel fluoride deposition. Am J Dent 1994;7:119-121.

16. Duckworth RM, Morgan SN, Murray AM. Fluoride in saliva and plaque following use of fluoride-containing mouthwashes. J Dent Res 1987;66:1730-1734.

17. Iijima $Y$, Koulouride T. Fluoride incorporation into and retention in remineralized. J Dent Res 1989;68:1289-1292.

18. Takagi S, Liao H, Chow LC. Effect of tooth-bound fluoride on enamel demineralization/remineralization in vitro. Caries Res 2000;34:281-288.

Accepted January 30, 2008 